\title{
Gadget Addiction and the Students' Achievement
}

\author{
Barotun Mabaroh $^{1 *}$ and Lilik Sugianti ${ }^{2}$ \\ ${ }^{1,2}$ Universitas PGRI Wiranegara Pasuruan, Indonesia \\ *e-mail: barotunmabaroh@yahoo.com
}

\begin{abstract}
Using gadgets cannot be avoided in daily life. It becomes more primary for students in higher education since they change to learn online during the covid-19 pandemic period. They should use gadgets focusing on education, but unfortunately, studies had reported that students are addicted to using gadgets to access some entertaining applications. Therefore, it was essential to investigate how the students manage using gadgets and their effects on their achievement. This survey research required the student's responses to a Gadget Scale-Short Version (SAS-SV) Addict item. The researchers collected data using a survey questionnaire on Google Form to determine how using gadgets affects the students' achievement. This research was done from August to December 2020. The results showed that both male and female students were identified as high-risk addicted. Moreover, the gadget addiction had terrible effects on the student's physical and psychological even though it did not significantly impact their academic achievement. However, based on the results, it was hoped that there should be the best management for using gadgets to improve the students' achievement and prevent the long-term risk of gadget addiction.
\end{abstract}

Keywords:

Addiction; Gadget; Students’ Achievement.

\begin{abstract}
ABSTRAK
Penggunaan gadget sudah tidak bisa dihindari dalam kehidupan seharihari. Gadget bahkan menjadi lebih utama bagi mahasiswa di pendidikan tinggi karena digunakan untuk perkuliahan online selama periode pandemi COVID-19. Seharusnya, mahasiswa menggunakan gadget untuk fokus pendidikan mereka, tetapi sayangnya beberapa penelitian melaporkan bahwa banyak mahasiswa kecanduan menggunakan gadget untuk mengakses beberapa aplikasi hiburan. Oleh karena itu, penting untuk
\end{abstract}


mengetahui bagaimana mahasiswa mengatur penggunaan gadget dan pengaruhnya terhadap prestasi belajar mereka. Para peneliti mengumpulkan data menggunakan kuesioner survei di Google Form. Kuesioner survei meminta tanggapan siswa terhadap item Kecanduan Gadget Scale-Short Version (SAS-SV). Penelitian ini dilakukan pada bulan Agustus hingga Desember 2020. Hasil penelitian menunjukkan semua mahasiswa, baik laki-laki ataupun perempuan kecanduan gadget dengan risiko. Bahkan, kecanduan gadget tersebut telah berdampak buruk terhadap kesehatan fisik dan psikologis meski ternyata tidak signifikan berimbas buruk pada capaian akademik mereka. Namun demikian, berdasarkan hasil penelitian ini, diharapkan ada pengaturan penggunaan gadget yang tepat agar dapat menunjang prestasi belajar siswa yang lebih baik dan mencegah resiko jangka panjang dari kecanduan gadget.

\section{Kata kunci:}

Kecanduan; Gadget; Prestasi Mahasiswa.

\section{Introduction}

The gadget is a cellphone with advanced features such as making phone calls, sending text messages, displaying photos, playing games, video, etc. At the same time, addiction is defined as any obsessive behavior that interferes with usual living and causes rigorous stress on family, friends, loved ones, and work performance (Un Nisa, 2018). The number of gadget users in Indonesia was estimated to reach 191.6 million users in 2021 In addition, states that Indonesia has become the fourth-largest gadget market worldwide after China, India, and the United States. Due to this fact, gadget addiction would be incredibly possible for students in Indonesia. Therefore, the researchers had been triggered to investigate how university students manage their use of gadgets and discover their impacts on their learning achievement (Nurhayati-Wolff, 2021).

Gadget addiction can be easily diagnosed by the duration spent using it. Previous research had contributed to the classification. First, Dell'Osso B et al. (2008) had identified that people with impulsive-compulsive Internet usage disorder (IC-IUD) used gadgets by a mean of 36.8 hours/week. Then, Karpinski et al. (2013) noticed that students used their gadgets for more than 6 hours per day. They also found that students used their gadgets for learning while, on the other hand, they also open social media or game sites during the class. Furthermore, Aljomaa et al. (2016) had justified addiction if people used the gadget for more than 8 hours per day. Next, Wahyuni et al. (2019) stated that the abnormal category based on the most hours of gadget usage is $>10$ hours. More specifically, Stephanie (2021) had reported that the average time spent by Indonesians to access the internet per day is 8 hours 52 minutes.

Activities make addiction to gadget are various. Niro et al. (2020) reported that $48 \%$ of 126 samples spent duration more than 12 hours using gadgets, and it, mostly, was for playing games $(29,5)$ and watching videos $(32,8 \%)$. Zencirci et al. (2018) also proved that social contacts and 
entertaining applications/content increase students' addiction to the gadget. Therefore, it is not surprising that people often used their gadgets to access entertaining applications and social simulation games like the Animal Crossing series or Minecraft. UNICEF (2020) has also reported that Steam as a representative of Digital game distributors, has achieved an increasing number of daily users over the past weeks: from 19 million in early March to a record high of 23.5 million in early April 2020, and it continues increasing up to now.

Related to the trend of online gaming, which makes gadget addiction, Dumrique and Castillo (2017) claimed that even though students play online games, they know how to socialize and perform very well in academic performance. Santha et al. (2012) also reported that the samples were using electronic gadgets excessively, but $90 \%$ of them had average/good academic performance. This means that gadget addiction did not significantly affect the students' poor achievement. Contrarily, Chasanah and Kilis (2018) found that gadget addiction influences family functioning negatively and implies academic achievement. Next, De Niro et al. (2020) reported that gadget addiction caused $76 \%$ of 72 male and female respondents to feel poor sleep quality; thus, they also got poor learning achievement. The researchers were curious to observe whether gadget addiction affects the students' achievement or not about these two different results.

This research was unique since it would discover gadget addiction and students' academic achievement during the period of pandemic covid 19 when people operate their gadgets in more many hours. Any educators should notice this research result because this could evaluate risks of gadget addiction which may give negative consequences to many aspects, especially the students' achievement (Starcevic, 2019). Beside, this research result would be beneficial for educators to guide how students should manage using gadgets and achieve better learning.

\section{Methods}

The research was survey research. It used a close questionnaire as the instrument. The data collection was done by distributing a close questionnaire to respondents through Google Form. Then, the link of the questionnaire was distributed to the targeted respondents by broadcast messaging on Whatsapp. The questionnaire consisted of a list of statements and questions with several choices adapted from Kwon et al. (2013). The researchers adapted ten items from Kwon et al. SAS-SVwhich were closely related to identifying the level of gadget addiction and its risks for university students. The internal consistency and concurrent validity of the questionnaire were verified $($ Cronbach's alpha $=0.876)$. Each subscale was significantly correlated with K-scale and Yscale. So, it was proven that the questionnaire had high reliability and validity.

The research subject was Universitas PGRI Wiranegara from the English Education Study Program, Indonesian Language and Literature Study Program, Economics Education Study Program, Islamic Education Study Program, Mathematics Education Study Program, and Civic Education Study Program. To ease the respondents, the researchers provided the survey form in Bahasa Indonesia. Before the respondents answer the survey form, the researchers ensured that the 
respondents provide accurate information without any coercion from the researchers or any stakeholder.

The Gadget Scale-Short Version (SAS-SV) used here was four statements that should be answered by a 6-point Likert scale ranging from strongly agree, agree, instead agree, disagree, disagree, and strongly disagree. The four statements were about 1) Missing planned works due to playing the gadget, 2) Having a hard time concentrating in class or while doing assignments due to the gadget use, 3) Neglecting matters other than gadget use even when there are many assignments to be done, and 4) I will never give up using my gadgets even when my daily life is already greatly affected by it.

To analyze the data, the researchers converted responses of strongly agree(6), agree(5), rather agree(4), rather disagree(3), disagree(2), strongly disagree(1). Then, the Level of Addiction was accumulated by using this formula $L A=\Sigma S: \Sigma R * 4$. Both male or female respondents were classified with high-risk addiction if their scores are from 20-24. Score 16-19 was latent, whereas 12-15 was low risk. Normal (not addicted) was scored1-8. The researchers then differ male and female students' mean scores because it could contribute to gender factor analysis.

After discovering the students' level of addiction, the researchers also required the respondents to answer six questions based on their experience using the gadget. They were 1) Your gender, 2) Your GPA now, 3) How long do you use your gadget throughout the day?, 4) How do your physical feel after you use gadgets for a long time?, 5) How do the psychological feel after you use a gadget for a long time?, and 6) What types of activity do you often do while using gadget? The respondent's gender would be presented in percentage, while the GPA was classified based on the Academic Recognition of Universitas PGRI Wiranegara, Indonesia. Numbers of percentage would analyze the harmful physical and psychological effects. It also prevailed for the activities done while using gadgets.

\section{Results and Discussion}

In this part, the researchers would describe results given by the respondents. The researchers distributed the questionnaire to more than 200 respondents by random sampling, but the submission was only 76. The gender of gadget users who were involved in responding to the questionnaire is seen below. 


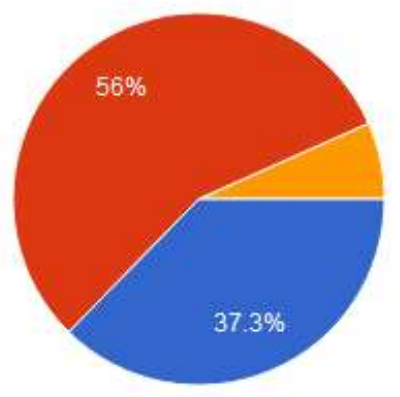

Figure 1. Respondent gender

The red was referred to female respondents $(56 \%)$, while the blue was for male respondents $(37,3 \%)$. The orange was unknown; it may be because of the respondents' ignorance of state gender $(6,7 \%)$. For this case, the researchers converted $6,7 \%$ (orange) based on the percentage of female and male respondents. This data represented the respondents only but cannot be generated as the actual number of gadget users. Furthermore, the researchers would describe gadget addiction by gender.

\subsection{Level Addiction by Gender}

From 76 respondents, the researchers could evaluate the data of the SAS-SV Addict item in this survey as the following.

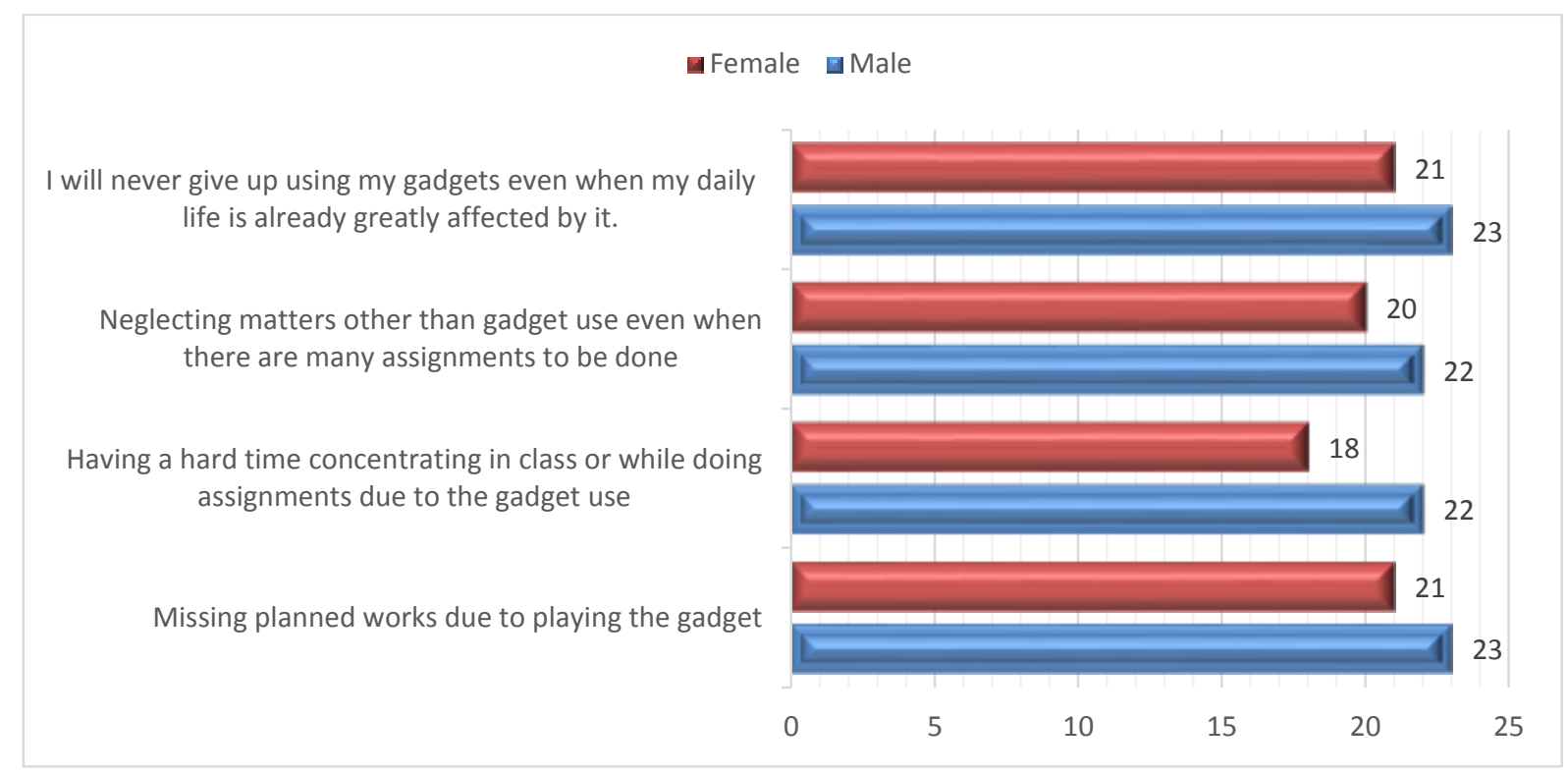

Figure 2. Result of SAS-SV Addict Item 
From the chart, the score of Missing planned works due to playing the gadget for male students was 23. Next, Having a hard time concentrating in class or doing assignments due to the gadget use was 22. Neglecting matters other than gadget use even when there are many assignments to be done was 22, and I will never give up using my gadgets even when my daily life is already greatly affected by it was 23. Based on this data, the researchers got the mean of male students' score 22,5 and classified them as the high-risk addicted.

Female students were also classified as the high-risk addicted with the lowest mean of 20. It was formulated by looking up their response score on Missing planned works due to playing the gadget was 21. Next, Having a hard time concentrating in class or doing assignments due to the gadget use was 18. Neglecting matters other than gadget use even when there are many assignments to be done was 20, and I will never give up using my gadgets even when my daily life is already greatly affected by it was 21 .

Although both males and females were categorized as high-risk addicted, the mean showed a difference of 2,5. Related to this difference, Su, Han, Jin, Yan, \& Potenza (2019) state that genderrelated differences exist in most addictive behaviors. In more specific, Anderson et al. (2017)revealed that males are at a higher apparent risk for internet access than females based on seven studies across different cultural groups.

Male and females were not different in terms of the mean level of addiction; they were also different in online activity types. Nayak (2018) states various activities done by users with many different statuses in using the gadget. In a hierarchy, the researchers found that the male students used the gadget to watch YouTube and movies, send messages and call with others, search for some material for doing the assignments, listen to music, and play games. While, the researchers found that the female students used the gadget for opening social media such as Instagram and Facebook, playing TikTok, making Vlog, selfies, sending messages and calling with others, searching for some material for doing the assignments, and doing the online business.

The different ranks of activity done by male and female students may be influenced by many aspects, including their emotions. According to Starcevic (2019), females tend to be more curious about any emotional information such as gossip on social media than men. Females could also express their emotions easily on Facebook or Instagram; thus, it is not deniable that accessing social media had been the first rank activity they prefer. In addition, Pratama (2018) proved that females often used gadgets for communicating on social media, but the male used the gadget to enjoy himself, such as watching YouTube and playing various games.

\subsection{The Physical and Psychological Effects}

Gadget addiction could have negative consequences or harmful effects on the users for a long time (Starcevic, 2019). The harmful effects of gadget addiction decreased physical and psychological health (Panova, Tayana, \& Carbonell, 2018). Gadget users spend so much time 
though they might already feel pain in their wrist, at the back of their neck, and in their eyes, head, etc. (Kwon et al., 2013). This research evaluates three physical effects felt by the respondents

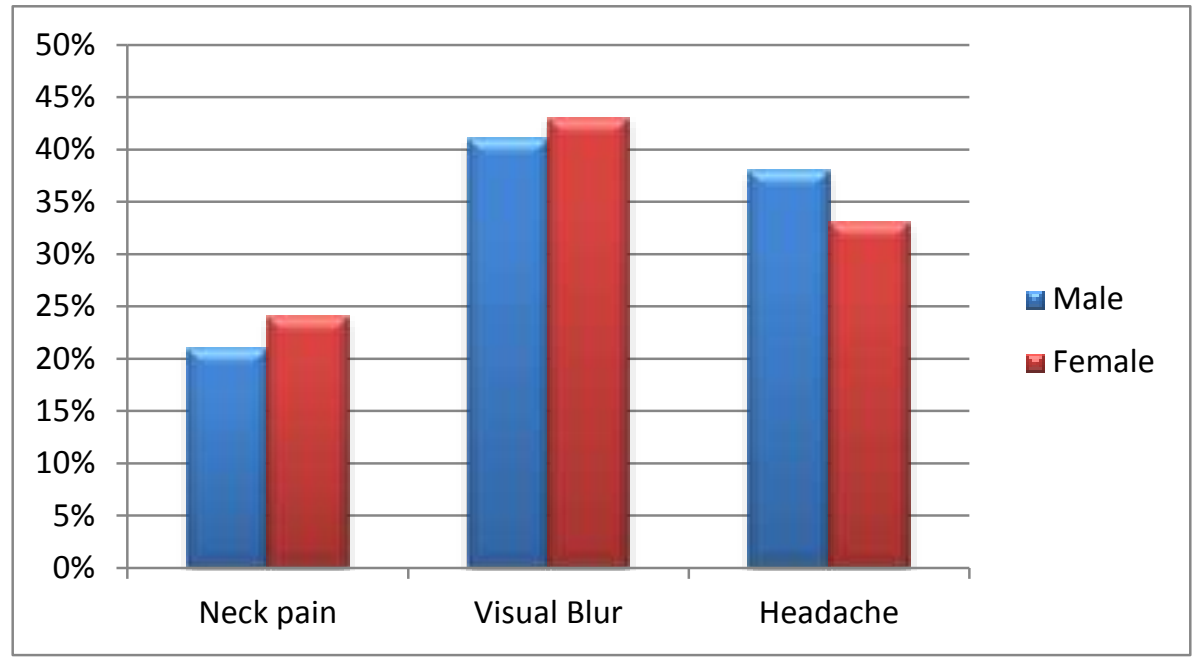

Figure 3. Physical Effects

This research finding supported Sadagopan et al. (2017) statement that females with digital tools were at a significantly higher risk of eye strain. The eye strain causes visual blur and, based on the data; visual blur was the most physical effect felt by the respondents in this research. Visual blur can also be called visual fatigue. According to Park et al. (2017), visual blur or fatigue possibly reduces the ability to balance, so it is necessary to take appropriate rest of using a gadget or affect psychological syndrome.

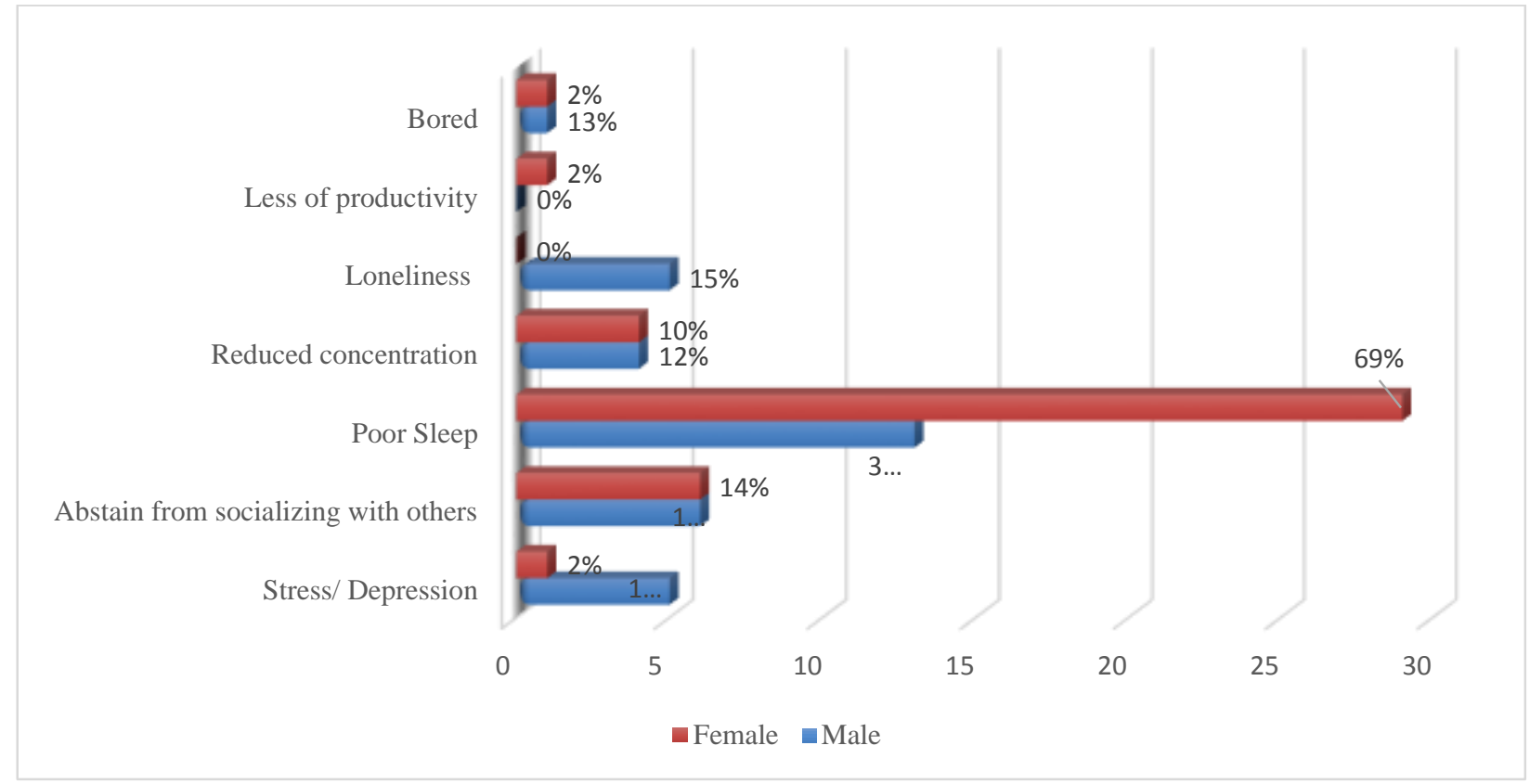

Figure 4. The Psychological Effects 
The researchers found poor sleep as the most psychological effect of gadget addiction experienced by the respondents. The harmful effects for male students were $15 \%$ of students felt stress/depression, $18 \%$ of students abstained from socializing with others in real life, $38 \%$ of students experienced poor sleep, $12 \%$ of students were reduced on concentration, $15 \%$ of students felt loneliness, and 3\% students got bored. The harmful effects for the female's students were $2 \%$ of students felt stress/ depression, $14 \%$ of students abstained from socializing with others in real life, $69 \%$ of students got poor sleep, $10 \%$ of students were reduced concentration, $2 \%$ of students were less productivity, and $2 \%$ of students were bored.

Poor sleep in this research was associated with insufficient time and dissatisfaction after sleep (Alfian et al., 2018). This lousy effect was psychological because it annoys them to sleep well due to gadget addiction. Students should realize that they experienced sleep loss and sleep disorders because of gadget addiction which are among the most common yet frequently overlooked and treatable (Institute of Medicine (US) Committee on Sleep Medicine and Research, 2006). Poor sleep is the potential cause that makes people worried dan unconcentrated. Moreover, Alhola \& Polo-Kantola (2007) argue that total sleep deprivation due to gadget addiction impairs attention and working memory, but it also affects other functions, such as long-term memory and decisionmaking. In other words, recovering from it need attention before students must treat themselves with cognitive recovery processes.

\subsection{Gadget Addiction and Academic Achievement}

The researchers set Grade Point Average (GPA) as the indicator of academic achievement. Students must study hard to achieve the highest GPA and have entirely concentrated during the learning process. The researchers would evaluate whether gadget addiction's physical and psychological effects contributed to the student's GPA. The researchers classified the GPA based on the Academic Recognition in Universitas PGRI Wiranegara, Indonesia.

Table 1. Grade Point Average (GPA) Conversion

\begin{tabular}{ccccc}
\hline No & Symbol & Scale & $\begin{array}{c}\text { Max } \\
\text { Conversion }\end{array}$ & Qualification \\
\hline 1 & A & $91-100$ & 4.00 & High distinction \\
2 & A- & $84-90$ & 3.75 & Distinction \\
3 & B+ & $77-83$ & 3.50 & Honor \\
4 & B & $71-76$ & 3.25 & Satisfaction \\
5 & B- & $66-70$ & 3.00 & Credit \\
6 & C+ & $61-65$ & 2.75 & Pass \\
7 & C & $55-60$ & 2.50 & Near pass \\
8 & D & $41-54$ & 2.25 & Fail \\
9 & E & $0-40$ & 2.00 & Withdrawn fail \\
\hline
\end{tabular}

From 76 respondents, the researchers could find describe the students' GPA scale as the following. 


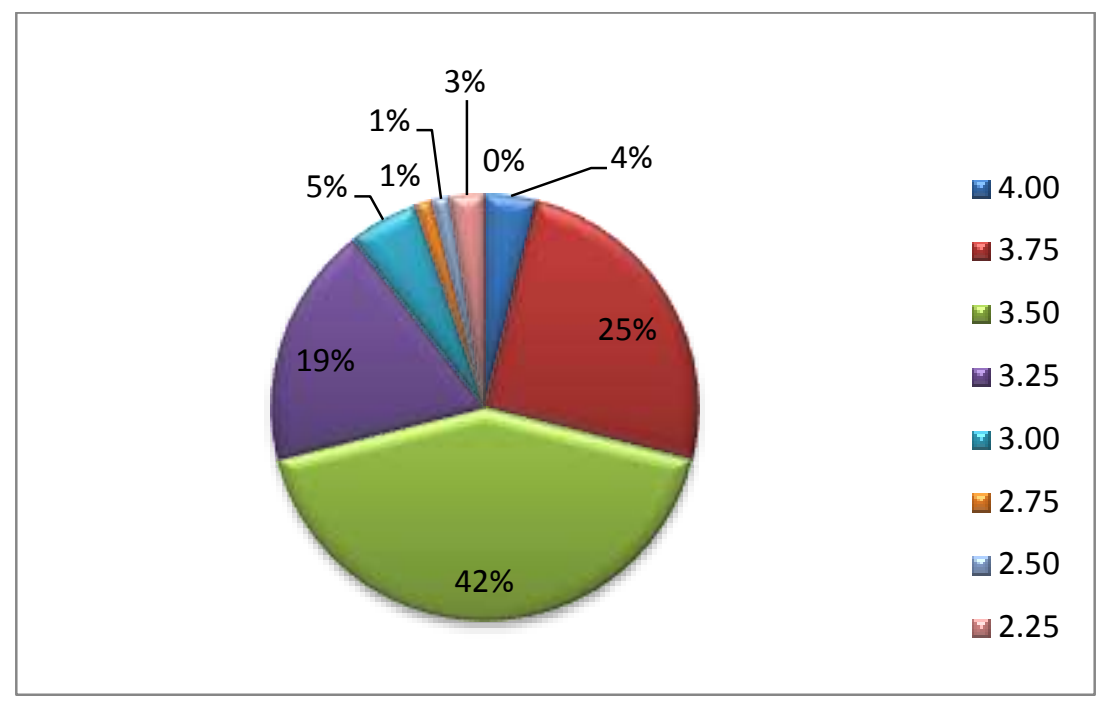

Figure 5. The students' GPA

The conversion from 3.26-3.5 is shown as the highest percentage of students' GPA, and 32 students achieved it. Next, 19 students achieved a better range of 3.51-3.75. The other high percentage was for the score conversion from 3.01-3.25. This data was surprising to the researchers since the students were classified as high-risk addicted, but they could still make exemplary achievements. Only eight students or $10 \%$ of the total respondents cannot achieve at least 3.01, which means $90 \%$ of students could pass it. In other words, this research supported Dumrique \& Castillo's (2017) statement, which claimed that students could know how to socialize and perform very well in academic performance although they play online games for many hours. This research finding also proved that excessive gadget usage was not a significant cause for the students' poor achievement (Santha et al., 2012). Last, this research had also come to a similar conclusion with Sheppard \& Wolffsohn's (2018) research which claimed that usage of digital devices for many hours each day is now normal; thus, researches about the relation between gadget addiction and the students' achievement need to develop more thoroughly.

However, the students should be aware of the potential risks of using gadgets, especially for physical and psychological long-term effects. Due to this, the researchers offer how to manage using gadgets in an educational setting. First, educators can reduce students' usage of the gadget by designating specific non-digital hours and days during the teaching and learning process (KPC3 cited in Keumala, Yoestara, \& Putri, 2018). The sessions of using gadgets should follow a balancing pattern like implementing hybrid learning. Second, Sebayang (2020) suggests that both educators and students must set a limit on using the gadget and avoid it before bed. adds that people should use gadgets as urgently as needed and change wasting digital activities into sports, caring for pets, gardening, etc. (Sebayang, 2020) 


\section{Conclusions}

This research was aimed at discovering how the students use gadgets and evaluate their risks. The students were found to the high-risk addicted to gadgets. It was proved by their attitude, which often missing planned works, having hard concentrating in class or while doing assignments, preferring playing gadgets even there are many assignments to be done, and using gadgets with all consequences. The students felt visual blur, headache, and neck pain because of playing the gadget for hours. They also experienced negative psychological states like poor sleep, loneliness, abstain from socializing with others, reduced concentration, loss of productivity, boredom, and stress/ depression. Surprisingly, the students achieved good academic qualifications despite having negative consequences of gadget addiction for their physical and psychological. Even so, students must realize that the risks may affect the long-term condition, so they need to manage using gadgets more wisely and safely. This research finding implied that gadget addiction, both for male or female students, did not make the academic achievement poor or worst. However, further research is to justify or reexamine this research finding due to the students' development for a more comprehensive understanding.

\section{References}

Alhola, P., \& Polo-Kantola, P. (2007). Sleep Deprivation: Impact on Cognitive Performance. Neuropsychiatric Disease and Treatment, 3(5), 553-567.

Aljomaa, S. S., Mohammad, M. F., Albursan, I. S., Bakhiet, S. F., \& Abduljabbar, A. S. (2016). Smartphone addiction among university students in the light of some variables. Computers in Human Behavior. DOI: https://doi.org/10.1016/j.chb.2016.03.041.

Anderson, E. L., Steen, E., Stavropoulos, V., Louise, E., Steen, E., \& Stavropoulos, V. (2017). Internet use and Problematic Internet Use : a systematic review of longitudinal research trends in adolescence and emergent adulthood Internet use and Problematic Internet Use: a systematic review. International Journal of Adolescence and Youth, 3843, 1-25. DOI: https://doi.org/10.1080/02673843.2016.1227716.

Chasanah, A. M., \& Kilis, G. (2018). Adolescents' Gadget Addiction and Family Functioning, 139 (Uipsur 2017), 350-358. DOI: https://doi.org/10.2991/uipsur-17.2018.52.

Dell'Osso B, Hadley S, Allen A, Baker B, Chaplin WF, H. E. (2008). escitalopram in the treatment of impulsive-compulsive internet usage disorder: an open-label trial followed by a doubleblind discontinuation phase. Journanl Clin Psychiatry, 69(3), 452-6. DOI: https://doi.org/10.4088/jcp.v69n0316.

Un Nisa, Zaka. (2018). Gadget Addiction Emergence of Mental Illness in Youth - ISEST. Retrieved from https://www.isest.org/gadget-addiction-emergence-of-mental-illness-in-youth/

Dumrique, D. O., \& Castillo, J. G. (2018). Online gaming: Impact on the academic performance and social behavior of the students in polytechnic university of the philippines laboratory high school. KnE Social Sciences, 3(6), 1205. DOI: https://doi.org/10.18502/kss.v3i6.2447

Institute of Medicine (US) Committee on Sleep Medicine and Research. (2006). Sleep Disorders and Sleep Deprivation: An Unmet Public Health Problem. (B. Colten, HR., Altevogt, Ed.). Washington (DC): National Academies Press (US). Retrieved from https://www.ncbi.nlm.nih.gov/books/NBK19961/.

Karpinski, AC., Kirschner, P,.Ozer,I., Mellott,JA,. Ochwo,P. (2013) An exploration of social networking site use, multitasking, and academic performance among united states and 
european university students, Computers in Human Behavior 29(3):1182-1192. DOI:10.1016/j.chb.2012.10.011

Keumala, M., Yoestara, M., \& Putri, Z. (2018). The impacts of gadget and internet on the implementation of character education on early childhood. Proceedings of the ICECED, 313325.

Kwon, M., Lee, J., Won, W., Park, J., Min, J., Hahn, C., Kim, D. (2013). development and $\begin{array}{lllll}\text { validation of a smartphone addiction } & \text { scale }\end{array}$ DOI:https://doi.org/10.1371/journal.pone.0056936

Nayak, J. K. (2018). Relationship among smartphone usage, addiction, academic performance and the moderating role of gender: a Study of higher education students in India. Computers \& Education, 123(1), 164-173.

Niro, De AJN., Pawitra, A., Faizah,NN., Putra, RD., et.al. (2020). Correlation Of Gadgets Addiction With Sleep Quality In 4th - 6th Grade Students At Sdn 01 Srigading Lawang In 2019 Journal Community Medicine Public Health and Research Vol 1, No 2, 1(2), 80-88. DOI: http://dx.doi.org/10.20473/jcmphr.v1i2.21699.

Nurhayati-Wolff, H. (2021). Internet usage in Indonesia - statistics \& facts, from https://www.statista.com/statistics/266729/gadget-users-in-indonesia/.

Panova, Tayana,m \& Carbonell, X. (2018). Is smartphone addiction really an addiction? Journal of Behavioral Addictions, 7(2), 252-259. DOI: https://doi.org/10.1556/2006.7.2018.49

Park, Young-Hyun., An, Chang-Man., and Moon, S.-J. (2017). Effects of visual fatigue caused by smartphones on balance function in healthy adults. Journal of Physical Therapy Science, 29(2), 221-223. DOI:https://doi.org/10.1589/jpts.29.221.

Pratama, A. R. (2018). Investigating Daily Mobile Device Use Among University Students in Indonesia. IOP Conf. Ser.: Mater. Sci. Eng. 325 012004. DOI:https://doi.org/10.1088/1757899X/325/1/012004.

Sadagopan, A. P., Manivel, R., Marimuthu, A., Nagaraj, H., \& Ratnam, K. (2017). Prevalence of Smart Phone Users at Risk for Developing Cell Phone Vision Syndrome among College Students, Journal of Psychology \& Psychotherapy, 7(3). DOI:https://doi.org/10.4172/21610487.1000299.

Santha, NJ., (2012). Certificate Influence of Electronic Gadgets Excessive Use on Academic Performance and Family Interaction Among Adoloscents Approved By the Dissertation. Retrieved from DOI: http://repository-tnmgrmu.ac.in/4354/1/3005055estherjennifers.pdf

Sebayang, S. (2020). Discussing the danger of gadget addiction and how to overcome through lecturer community service - Unair News.

Sheppard, A. L., \& Wolffsohn, J. S. (2018). Digital eye strain: Prevalence, measurement and amelioration. BMJ Open Ophthalmology, 3(1). DOI: https://doi.org/10.1136/bmjophth-2018000146.

Starcevic, V. (2016). Behavioural addictions: A challenge for Psychopathology and Psychiatric Nosology,Australian and Zew Zeland Journal of Phsychiatry, 50 (8), 721-725. DOI: https://doi.org/10.1177/0004867416654009.

Stephanie, Conney .(2021). Berapa Lama Orang Indonesia Akses Internet dan Medsos Setiap Hari? Kompas.Com. Retrieved from https://tekno.kompas.com/read/2021/02/23/11320087/berapalama-orang-indonesia-akses-internet-dan-medsos-setiap-hari-?page=all .

Su, W., Han, X., Jin, C., Yan, Y., \& Potenza, M. N. (2019). Computers in Human Behavior Are males more likely to be addicted to the internet than females? A meta-analysis involving 34 global jurisdictions. Computers in Human Behavior, 99, 86-100. DOI: 
https://doi.org/10.1016/j.chb.2019.04.021.

UNICEF. (2020). Rethinking screen-time in the time of COVID-19 | UNICEF Office of Global Insight \& Policy. Retrieved from https://www.unicef.org/globalinsight/stories/rethinkingscreen-time-time-covid-19.

Wahyuni, A. S., Siahaan, F. B., Arfa, M., Alona, I., \& Nerdy, N. (2019). The relationship between the duration of playing gadgets and mental, emotional state of elementary school students. Open Access Macedonian Journal of Medical Sciences, 7(1), 148-151. DOI: https://doi.org/10.3889/oamjms.2019.037.

Zencirci, Akbulut S., Aygar, H., Göktaş, S., Önsüz, M. F., Alaiye, M., \& Metintaş, S. (2018). Evaluation of smartphone addiction and related factors among university students. International Journal of Research in Medical Sciences, 6(7), 2210. DOI: https://doi.org/10.18203/2320-6012.ijrms20182805. 